\title{
Jenny Haase
}

\section{Utopías, distopías, heterotopías. El sur como lugar de memoria en Argentina y Chile:

\author{
Sur, de Fernando Solanas, y La frontera, \\ de Ricardo Larraín
}

\begin{abstract}
El sur se acaba cuando se encuentra. Con lo cual nos estamos poniendo en viajeros constantes.

España, en Pons/Soria (2005: 271).
\end{abstract}

\section{Introducción}

Caracterizado por su localización periférica tanto a nivel geográfico como político-cultural, el sur argentino y chileno es un lugar de atributos extremos que, desde siempre, ha provocado innumerables deseos y fantasías, pero también ha sido un lugar generador de miedos profundos. Así, por ejemplo, ya en la toponimia de la zona más austral del continente americano encontramos reflejada esta dualidad contradictoria: por un lado, tenemos los nombres de lugares que remiten a la frustración, al malestar y a la experiencia del fracaso relacionados con los primeros intentos de colonización por los exploradores e inmigrantes europeos, como Puerto Hambre, Isla Desolación, etc. Por otro lado están los toponimios de origen patriótico del siglo XIX que aluden a una utopía nacional del progreso, sobre todo en el terreno argentino (Lago Argentino, Cerro de Mayo, Lago San Martín, etc.), rememorando así las esperanzas e ideales de los colonizadores.

En las últimas dictaduras militares en Argentina (1976-1983) y en Chile (1973-1989), los regímenes militares ejercieron una fuerte violencia dentro del contexto del terrorismo de Estado en la zona austral, tal como en el resto del territorio de ambos países. Ambos regímenes se aprovecharon, en especial, del aislamiento geográfico y del clima inhóspito de la región, mandando activistas de la oposición al destierro e instalando prisiones y también centros de detención, en los que 
se solía ejercer el maltrato físico y psíquico, la tortura y la ejecución de presos políticos. Ushuaia o Trelew en Argentina y la Isla Dawson en Chile son nombres que remiten de manera metonímica al terror del Estado en esta época reciente. ${ }^{1}$

Dos películas paradigmáticas me van a servir como punto de partida para reflejar los significados ambivalentes que ha adquirido la región austral en las representaciones culturales de las primeras fases postdictatoriales en relación con la memoria histórica en Argentina y Chile: Sur, de Fernando Solanas (Argentina, 1988) y La frontera (Chile, 1991), de Ricardo Larraín. Para ello, me voy a centrar en el imaginario del sur como una manera de construir una memoria (trans)nacional, analizando su puesta en escena como espacio utópico, distópico o heterotópico, es decir, su calidad de representar "un lugar otro" fuera de la realidad o de la normalidad social.

Cabe preguntar si el sur ha llegado a representar en los dos países no sólo un "lugar de la memoria", es decir, un lugar cuya historia (fragmentada) se va recordando paso a paso, sino también un "lugar de memoria" ("lieu de mémoire") en el sentido del historiador francés Pierre Nora. Los lugares de memoria, según Nora, comprenden al mismo tiempo aspectos materiales, simbólicos y funcionales y pueden incluir las formas de memoria más diversas, desde un lugar u objeto concreto, como una región o un monumento hasta un mito o un personaje importante, pasando por los archivos y obras de arte (Nora 1984). En el contexto argentino, se podrían mencionar, por lo tanto, lugares de memoria tan diferentes como el antiguo centro de tortura de la ESMA (Escuela de Mecánica de la Armada), las actividades del grupo de las Madres de la Plaza de Mayo o monumentos como el Parque de la Memoria en Buenos Aires; en el caso chileno, por ejemplo, el antiguo centro de tortura Villa Grimaldi o la figura de Salvador Allende. Se trata de descubrir entonces si a través de las representaciones culturales recientes, la región austral argentina y chilena se va transformando asimismo en un lugar simbólico donde se cristaliza la memoria postdictatorial de los dos países.

1 Para la Patagonia argentina, véase, p.ej., Dujovne Ortiz (1996); para Chile, véase Bizzarro (2005: 166, 214-215). 


\section{Sur: desplazando las experiencias y esperanzas extremas a la periferia}

Sur de Fernando Solanas no sólo evoca el viejo mito del sur argentino, ${ }^{2}$ sino que la película y su director se han vuelto, a su vez, un mito, sobre todo en el imaginario de la izquierda argentina e internacional. Solanas se dio a conocer como director comprometido con su película La hora de los hornos (1968), documental que denuncia las prácticas neocoloniales y la violencia en América Latina y que obtuvo el reconocimiento internacional. Películas como Tangos... el exilio de Gardel (1985), El viaje (1992) y, más recientemente, Memoria del saqueo (2004), también obtuvieron una gran difusión y valoración a nivel mundial. Con su compromiso político continuo, Solanas representa hasta hoy una voz importante dentro del discurso cultural y político de la izquierda argentina.

Sur se estrenó en 1988, cinco años después del fin de la dictadura en Argentina, y refleja, de manera poética y narrativamente compleja, las distintas experiencias dolorosas bajo el régimen militar. ${ }^{3} \mathrm{~A}$ la caída de la dictadura, el protagonista, Floreal, vuelve a Buenos Aires tras pasar cinco años encarcelado en la Patagonia. La película se centra en la noche de su vuelta a casa, pero el argumento abarca todo el período de los años del terror. La cámara se mueve entre imágenes realistas y "surrealistas" (Foster 1992: 97), produciendo una estética cinematográfica de collage que mezcla el lirismo con el panfleto y el realismo con un distanciamiento brechtiano (Oubiña 1994: 77). La narración fragmentada subraya el proceso de re-construcción de la memoria a nivel estructural. Al compás de la música de tango de Astor Piazzolla, Floreal se tiene que enfrentar a los fantasmas del pasado y del presente: así, se cruza con su familia, sus amigos y su mujer, enterándose de las preocupaciones de los que habían quedado atrás en Buenos Aires. Poco a poco se da cuenta de sus propias emociones contradictorias que oscilan entre la rabia, la culpa, los celos, la incertidumbre y la esperanza.

2 Véase, para tan sólo mencionar algunos ejemplos, la famosa revista de cultura Sur, el cuento de Borges con el mismo título o las numerosas proyecciones de la Patagonia desde el siglo XVI hasta hoy en día.

3 Sur ganó en 1988, entre otras distinciones, el premio a la mejor dirección en el Festival de Cine de Cannes y el premio a la mejor película en el Festival de Cine de La Habana. 
Obviamente, ya el título "Sur" subraya el destacado papel que adquiere este punto geográfico en el film. Sin duda, el título hace pensar al espectador primero en la dimensión utópica representada por el llamado "Proyecto Sur": este nombre se refiere a un grupo de militantes, amigos de Floreal, que acostumbran reunirse en la Capital para pensar la utopía de una sociedad más justa, "la utopía de los hombres libres del sur" (00:29:30). En una entrevista extensa con el periodista Horacio González, Fernando Solanas ha planteado su concepción ideológica del "Proyecto Sur" y de "la mesa de los sueños" (Solanas 1989: 37-38). En la película, son cuatro amigos que se suelen reunir en el Café Sur para discutir sus planes y visiones: un intelectual político militante, Emilio Ortiz; el dirigente obrero, Julián Etchegoyen; un militar oficial, Aníbal Rasatti, que trabaja en el Proyecto nacional Sur para la

independencia nacional y democratización de una sociedad donde la riqueza se distribuya con criterios de igualdad y justicia; liberación de las ataduras colonialistas de las patrias financieras y multinacionales (Solanas 1989: 40);

además, está el cantante Amado que, según Solanas, representa a las masas populares. Solanas destaca que se ha inspirado en pensadores liberales de la Historia argentina, como Raúl Scalabrini Ortiz, Arturo Jauretche, Hernández Arregui y César Marco, "intelectuales que combatieron el pensamiento colonial, el autoritarismo y la tortura" (Solanas 1989: 41). Las alusiones evidentes al Peronismo, expresadas en imágenes a veces poéticas, a veces grotescas, motivaron fuertes polémicas en Argentina (Ciria 1995: 207).

Entre otras cosas, el grupo de amigos arma un archivo para oponer resistencia a los censores de la dictadura, pero también para recuperar la memoria olvidada que ha sido censurada por la dominancia del "norte" (00:28:5-00:29:10). En este sentido, el sur simboliza la resistencia, tanto contra el régimen de la dictadura como contra la hegemonía cultural de los países industrializados del norte. ${ }^{4}$ Asimismo, con el proyecto se destaca de manera explícita y autoreflexiva la importancia del trabajo de la memoria cultural para la identidad colectiva y

4 "[La secuencia en el archivo] yuxtaposes South, as an authentic, national, human space, and North, as the space of pretentious and ultimately oppressive metropolitanism" (Foster 1992: 102). 
el procesamiento del pasado. En cambio, en una secuencia completamente opuesta a esta labor constructiva, el espectador es testigo de un acto grotesco y destructor en el que las voces democráticas y heterogéneas de la cultura nacional e internacional son silenciadas: nos encontramos en una oficina de censura en la que los libros más diversos, de autores como Freud, Freire, Sartre, y también Foucault, son calificados de "subversivos", "marxistas", "peronistas", "inmorales" o "pornográficos" e inevitablemente suprimidos por la censura.

En el plano acústico, el tango "Vuelvo al sur" que se escucha a lo largo de la película, refuerza la idealización del espacio que remite más a un estado de ánimo que a un espacio geográfico localizable: a la utopía de una vida más humana y solidaria. ${ }^{5}$ Solanas explica que este tema representa "un tango Sur al revés" (Solanas 1989: 177) ya que conlleva un significado menos melancólico que el conocido tango "Sur" del inicio. Según explica el director, escogió el primero para el final de la película a fin de sugerir un futuro optimista y positivo (Solanas 1989: 169).

A la par de este uso simbólico-discursivo, el término "Sur" también designa referentes geográficos y concretos. El título remite mayormente a la parte sur de la capital argentina y, en especial, al Café Sur, punto neurálgico en el enrejado de relaciones políticas y emocionales de los personajes. Foster nos recuerda que la parte sur de la ciudad de Buenos Aires ha sido un lugar que ha inspirado a muchos autores argentinos del siglo XX, como, por ejemplo Borges o Sábato (Foster 1992: 96). Para el propósito de este análisis, sin embargo, me voy a concentrar más en las secuencias ambientadas en la geografía sur del país.

Así, en una trama secundaria, la acción se traslada a la región austral: tras su arresto en Buenos Aires y el asesinato de su pareja por los militares, la joven María, amante de Floreal en las noches de huida y miedo en la capital, decide escapar a la Patagonia para buscar un espacio de refugio y reposo. La puesta en escena de este viaje comparte

5 "Vuelvo al Sur, como se vuelve siempre al amor, vuelvo a vos, con mi deseo, con mi temor. Llevo el Sur, como un destino del corazón, soy del Sur, como los aires del bandoneón. Sueño [aquí hay para comentar más sobre la idealización del espacio] el Sur, inmensa luna, cielo al revés, busco el Sur, el tiempo abierto, y su después. Quiero al Sur, su buena gente, su dignidad, siento el Sur, como tu cuerpo en la intimidad. Te quiero Sur, Sur, te quiero" (02:00:38-02:02:00). 
analogías con las imaginaciones utópicas por parte del "Proyecto Sur". En el momento en que María y un amigo camionero, con el significativo nombre de "el Peregrino", llegan a la Patagonia, la cámara nos muestra un plano general de un hermoso y luminoso paisaje cuya vastedad parece infinita y en cuyo horizonte la luz del alba parece prometer un futuro mejor (00:52:25). ${ }^{6}$ Para María, la Patagonia sugiere la posibilidad de una nueva vida, un volver a los valores humanos y a la esencia de sí misma, a su vez también una especie de exilio interior. El tema "Vuelvo al sur", que se escucha en esta secuencia en su versión instrumental, confirma la dimensión positiva del viaje. De este modo, el movimiento de María puede ser interpretado como el anhelo de volver realidad el abstracto "Proyecto Sur" de los amigos de la capital, ya que en la Patagonia espera encontrar un lugar "donde la vida y el deseo sean posibles" (00:52:47).

No obstante, las imágenes de esta puesta en escena positiva contrastan con planos del primer viaje de la mujer de Floreal, Rosi, y del mismo "Peregrino" a la Patagonia en busca de Floreal. Lo interesante es que las secuencias incluyen la superposición de las imágenes del paisaje, de tal manera que por unos momentos, las diferentes memorias y proyecciones del sur parecen confluir (00:53:00). De este modo, se destaca ya de manera visual la ambivalencia del imaginario del sur. Luego, en las imágenes posteriores, los colores fúnebres, la cronología (la acción sucede ahora de noche, y no ya por la mañana) y el encuentro con el preso visiblemente maltratado componen un cuadro totalmente opuesto a las sugerencias iniciales en las ensoñaciones de María y se convierten en un lugar de la memoria del terror.

A partir de este momento, las escenas retrospectivas que construyen los recuerdos de Floreal dominan sobre la imaginación positiva del sur del país. Aparentemente, Floreal es trasladado desde un centro clandestino de detención en Buenos Aires hacia distintos lugares de la Patagonia y la Pampa bonarense sin que al espectador se le informe dónde se encuentra exactamente ni de qué tipo de "cárcel" se trata; es decir, que el espectador llega a experimentar en su recepción una incertidumbre e inseguridad que se relacionan con las sensaciones, mu-

6 La secuencia hace pensar en un road movie, notorio género de muchas películas ambientadas en la Patagonia, como, más recientemente, Historias mínimas de Carlos Sorín. 
cho más intensas naturalmente, del protagonista y su familia. En lugar de representar un sitio o una forma de terror concretos, este encierro parece referirse a diferentes maneras de la violencia estatal bajo el régimen militar. Por ello, en lo siguiente será preciso tener en cuenta la ambigüedad del lugar que voy a denominar "cárcel-penal" por falta de indicaciones más concretas, pero que aparentemente comparte características de los centros de detención clandestinos, en los que se ejercía el terror y la tortura.

Los planos de la cárcel-penal se caracterizan, tal como la mayor parte de la película, por un color azul sombrío y muestran exclusivamente los espacios interiores de la prisión y sus alrededores. ${ }^{7}$ Por medio de estos flashbacks, el espectador se va enterando cada vez más de los sufrimientos de Floreal, que incluyen tanto el maltrato físico como la tortura psicológica, entre ellos el conocer sobre las ejecuciones de otros presos. Al mismo tiempo, asistimos a las dificultades y el distanciamiento crecientes entre Floreal y su mujer Rosi.

El lugar de la cárcel parece ser un lugar heterotópico, tal como lo plantea Michel Foucault (1994) en su ensayo "Des espaces autres". A la realidad de la Patagonia, que incluye su paisaje natural y el entorno social (si bien no aparecen representados explícitamente en el film) se opone este lugar de reclusión. La visión política del "Proyecto Sur" está denominada por este punto cardinal, pero no se puede localizar geográficamente, sino que representa más que nada un espacio discursivo y deseado, es decir, una utopía. En contraste, la cárcel es un lugar físicamente real y geográficamente localizable, a pesar de encontrarse a su vez fuera de la supuesta "normalidad" social, y por lo tanto representa una heterotopía (Foucault 1994: 756).

En este sentido, el penal patagónico, representa una heterotopía "de desviación", "celle dans laquelle on place les individus dont le comportement est déviant par rapport à la moyenne ou à la norme exigée" (Foucault 1994: 757). Foucault incluye las casas de reposo, las clínicas psiquiátricas y, explícitamente, las prisiones en este concepto. Como representante de la oposición, Floreal se desvía de la norma de obediencia y subordinación que impone el régimen militar.

7 Afirma Solanas que para él "la noche es el decorado natural de la reflexión y el amor, el decorado exacto de la poesía y el sueño así como también el de la muerte" (Solanas 1989: 33). 
Como consecuencia, al disidente se le desplaza a un lugar que se encuentra, de manera paradójica, al mismo tiempo fuera y dentro del espacio social, con el fin de disciplinarlo y mantener el orden del poder. Foucault compara el espacio heterotópico con un espejo ya que por un lado, la imagen reflejada en el espejo es de carácter virtual e irreal, y por otro lado, mantiene una relación estrecha con el espacio real, influyendo profundamente en la percepción del propio lugar. El espacio heterotópico sigue manteniendo la relación con la sociedad, aquí por ejemplo a través de las visitas controladas o de la comunicación por la ventana, y refleja la normalidad social que está representando, cuestionando e invirtiendo al mismo tiempo (Foucault 1994: 756). ${ }^{8}$

En la cárcel patagónica se va construyendo un espacio que, de manera especular, pretende reproducir la disciplina y el orden del interior en el exterior, es decir, en el resto de la sociedad. Con ello, según la tipología de Foucault, se trata aquí también de una "heterotopía de compensación" (Foucault 1994: 761) que busca controlar el desorden justamente tras establecer su contrario en un lugar delimitado. Habría que destacar, de todas maneras, que la misma "normalidad" argentina, en este caso ya está fuertemente marcada por la represión y violencia estatal, así que el lugar heterotópico tiene una función disciplinaria doblemente pervertida. Al fin y al cabo habría que considerar también en qué medida todos los sistemas dictatoriales producen lugares heterotópicos como consecuencia implícita del sistema y de qué manera estos espacios tendrán una función de modelo disciplinario para la sociedad que se pretende instalar.

Según Foucault, las heterotopías "supposent toujours un système d'ouverture et de fermeture qui, à la fois, les isole et les rend pénétrables" (Foucault 1994: 760). En la película, vemos cómo la mujer de Floreal, Rosi, está expuesta a las trabas del personal de seguridad al visitar a su marido (00:53:54-00:54:14). Luego, en el distanciamiento progresivo entre Floreal y su esposa se hace también muy visible

8 Para el caso de los centros de tortura argentinos, Pilar Calveiro afirma que "en tanto realidad negada-sabida, en tanto secreto a voces, son eficientes en la diseminación del terror. El auténtico secreto, el verdadero desconocimiento tendría un efecto de pasividad ingenua pero nunca la parálisis y el anonadamiento engendrados por el terror. Aterroriza lo que se sabe a medias, lo que entraña un secreto que no se puede develar" (Calveiro 2002: 237). 
cómo el preso va interiorizando cada vez más el estado de aislamiento. Acerca de las relaciones con el exterior en los centros de detención, afirma Calveiro que

[1]a distancia enorme y, al mismo tiempo la cercanía [...] crean la sensación de que el mundo externo ha "olvidado" al preso, es decir que se ha consumado la lógica concentracionaria. En la medida en que el prisionero cree en este olvido, resulta atrapado (Calveiro 2002: 175).

En Buenos Aires, Rosi empieza una relación amorosa con un amigo para poder sobrevivir al sufrimiento y al miedo. Como consecuencia, Floreal se refugia en la soledad: para soportar el dolor de los celos y del enajenamiento emocional, Floreal decide no ver más a su mujer. De este modo se hacen presentes los impactos psicológicos más profundos del sistema dictatorial: Floreal ha llegado a convertir el aislamiento físico en un encierro psicológico, adaptándose así, él mismo, a los valores ejercidos en el lugar heterotópico. Si al principio de su arresto el amor de su pareja todavía le otorgaba fuerza, su solidaridad y las fantasías eróticas le mantenían vivo, con el tiempo va interiorizando las reglas represivas del lugar con la consecuencia de que su pasión se vuelve contra él (01:34:00-01:39:24).

Así, las secuencias ambientadas en la Patagonia, a diferencia de la imaginación utópica, discursiva por parte del "Proyecto Sur" en Buenos Aires, ilustran experiencias extremas reales vividas bajo la dictadura. Por un lado, tenemos el tema del exilio interior, puesto en escena en la periferia como lugar de refugio (ilustrado por María). Por otro lado, está la referencia al confinamiento y la tortura que hemos visto localizados en el lugar heterotópico de la prisión (con el personaje de Floreal). En cualquier caso, la violencia y el terror, así como el anhelo de la solidaridad y el amor, son vivencias que se experimentan en la película tanto en Buenos Aires como en la región austral del país. Por eso, se puede decir que el film finalmente contradice su propia lógica binaria que opone un norte metropolitano y represivo a un sur puro, auténtico y humano. Así, el sur, en su función metafórica, ilustra los dos lados más contradictorios de la condición humana, el fracaso y la esperanza de una vida humana digna. 


\section{La frontera: el sur chileno como microcosmos permeable}

En La frontera de Ricardo Larraín, el sur chileno también es el escenario en el que se mezclan el miedo y la esperanza, el pasado y el futuro. Primer largometraje de la trayectoria del director chileno, la película fue galardonada con varios premios nacionales e internacionales, entre otros, el Oso de Plata a la mejor opera prima en el Festival de Cine de Berlín en el año 1992. Con El Entusiasmo (1999), Larraín volvería a tematizar la vida bajo el régimen de Pinochet, sirviéndose esta vez de un espectacular escenario natural del norte del país.

La frontera, escrita en 1986 y producida un año después de la recuperación de la democracia, es considerada por muchos críticos como la película de la transición chilena (Shaw 2003: 88; Carreño 2002: 83). El argumento se desarrolla en el año 1985, año que históricamente representa una fase de incrementadas protestas políticas, que fueron contestadas con una ola represiva por parte del régimen de Pinochet (Burriel 1998: 196). Sin embargo, la sensación de incertidumbre y de "terror latente" (Villaroel M. 2005: 164) refleja también temas y preocupaciones de la temprana posdictadura.

El protagonista Ramiro, profesor de matemáticas, es enviado como relegado político a una isla inaccesible "[en] alguna parte no identificada del sur de Chile" (Carreño 2002: 84) por haber firmado una carta de protesta en contra del arresto de un colega. El paisaje verde, nebuloso, el título y los lugares de rodaje, y, sobre todo, la presencia de la cultura mapuche, nos sugieren que se trata de la región araucana. ${ }^{9}$ Pero el referente geográfico pierde otra vez su centralidad frente a los elementos simbólicos y míticos: tal como en Sur, en La frontera también se renuncia a una representación mimética del espacio. En su lugar, la película pone en escena una sensación de violencia sutil, de miedo, de soledad y de falta de comunicación a través de la música, la atmósfera sombría y lluviosa, así como numerosas alusiones a la Biblia y a la mitología mapuche.

Las muchas configuraciones metafóricas invitan, en este contexto, a lecturas polisemánticas; mencionemos, por ejemplo, la presencia del mar, del maremoto, la isla, el buzo, etc. El constante empleo de imágenes metafóricas construye polivalencias semánticas que invitan a

9 La película fue rodada en los pueblos de Puerto Saavedra, Carahue y Nehuentué, en la IX región (cf. Carreño 2002: 90). 
lecturas no-fijadas de sentido, rodeando, como diría Nelly Richard, "imaginariamente lo ausente con una multiplicidad expresiva de connotaciones de sentido que desplazan la carencia hacia una pluralidad extensa de imágenes" (Richard 2003: 289). Volveremos a analizar estas imágenes más abajo.

En el destierro, Ramiro se ve confrontado con personajes representativos de la sociedad chilena. Tenemos ahí a los representantes del Estado en forma de funcionarios sumisos y conformes al régimen; un cura que busca mantener su neutralidad política; una chamana mapuche que cura al desterrado de una fiebre grave y prevé la llegada de un maremoto terrible; un buzo idealista que está buscando las posibles causas de este tipo de catástrofe natural habitual en la región; más dos exiliados españoles, que huyeron a Chile después de la Guerra Civil Española y que aluden a la vez a la situación de los chilenos exiliados fuera del país.

El sur contiene aquí un microcosmos de la sociedad chilena a finales de la dictadura y a principios de la transición, que representa de manera prototípica a las fuerzas sociales heterogéneas y a la vida cotidiana bajo la represión. El aislamiento geográfico de la zona, destacado todavía más por el espacio insular, refleja, en las palabras del director, "el sentimiento de estar fuera del mundo" de todo Chile, "un sentimiento que la dictadura acentuó probablemente" (Larraín, en Carreño 2003: 155). Resulta paradójico que la vastedad del espacio natural no ofrezca un área de proyección para fantasías de libertad, sino que es precisamente el contraste entre las imágenes de paisajes abiertos y, a su vez, melancólicos y el "encierro virtual" (Larraín, en Villaroel M. 2005: 112) de los personajes lo que nos transmite una sensación asfixiante. No se trata de un encierro físico forzado con rejas y muros, sino, en un nivel psicológico más profundo, del encierro internalizado de toda una sociedad. El sur chileno funciona aquí como pars pro toto de la experiencia dictatorial del país entero. Con ello, en oposición a la película de Solanas, en La frontera la zona sur no cumple tanto la función de espejo del lugar heterotópico o la de un espacio imaginario utópico, sino más bien la de un vidrio ustorio, o cristal de aumento.

Algunos críticos le han reprochado una "mirada conciliadora" (Carreño 2002: 83) a La frontera, considerando que no hay escenas que muestren la violencia física y psíquica de la tortura o que denun- 
cien abiertamente la desaparición de los más de tres mil chilenos bajo el régimen de Pinochet. ${ }^{10}$ De hecho, señalamientos similares se le habían hecho también a Solanas, reprendiéndolo por no mostrar más directamente la violencia a pesar de que en Sur, como hemos visto, sí hay referencias explícitas al maltrato y a la desaparición de personas. ${ }^{11}$ En efecto, La frontera no produce un discurso crítico en el sentido de una toma de posición militante. Sin embargo, también se podría argumentar que La frontera expone a su modo aspectos inquietantes de la dictadura, justamente porque borra las localizaciones unívocas de represión y oposición en un espacio fronterizo permeable. En este sentido, no localiza la violencia y la represión en un espacio aislado, como parece ser el lugar heterotópico en Sur sino que en La frontera estos aspectos forman una parte constitutiva de la "normalidad" social representada en la región austral. De todas maneras, con sus estéticas anti-miméticas, ambas películas proponen, cada una en su estilo, una elaboración crítica y sutil de la Historia reciente.

Así, en La frontera tenemos, como en Sur, alusiones al papel importante que se le otorga a la memoria en el proceso de democratización. Como resultado de un gesto de transposición, son aquí los personajes españoles los que personifican este ejercicio. La joven Maite trabaja como bibliotecaria del pueblo y busca rescatar la memoria cultural híbrida chilena ejemplificada, entre otros elementos, por unas leyendas mapuches que conserva en su archivo. Su padre, a su vez,

10 “Audiences are able to relate to Ramiro's experiences in a poetic, allegorical interpretation of Chilean history, without having to relive the most distressing events of the 1970s and 1980s. The coup of 1973 is never directly mentioned in the film, no murders or tortures are witnessed, and there are no brutal military men, only incompetent officials" (Shaw 2003: 89). Para una crítica más dura, véase Lillo (1995: 36-37): "La frontera [...] es [...] un fiel representante de la estética de la reconciliación [...] el humor en este filme banaliza la represión [...] contribuye a suavizar la imagen de los militares y se adhiere por esto a la hegemonía de la reconciliación. [...] La frontera es una película que no molesta a nadie en estos tiempos porque no cuestiona la actualidad chilena ni la pasada, sino que reconforta al espectador ofreciéndole la posibilidad de integrar el pasado inmediato a una identidad chilena exenta de conflictos."

11 Solanas sostiene que Sur es "símbolo o metáfora sobre el regreso de todo un pueblo, de un país a otro tiempo. [...] Es el traumático regreso del exilio interior y no un film sobre el exilio político, sobre la dictadura o los desaparecidos. Algunos quisieron encontrar eso y terminaron criticando la carencia" (Solanas 1989: 34). Larraín, a su vez, opina que La frontera no es una película política, sino que tematiza la busca de identidad chilena (cf. Carreño 2002: 83). 
colecciona fotografías de la Guerra Civil y viejos periódicos de la época del primer maremoto. Las alusiones a la memoria colectiva se presentan aquí más indirectas que en Sur ya que los textos y las fotografías mencionados no remiten directamente a la Historia política del país y mucho menos a las represiones bajo el régimen militar. En este sentido, resulta también significativo que el viejo exiliado menciona a Franco calificándolo de fascista mientras que nunca se alude a la figura de Pinochet.

No obstante, La frontera integra a su vez elementos utópicos y distópicos. Entre las metáforas centrales del film figuran tanto el maremoto, que en el pasado ya había afectado una vez al pueblo con consecuencias fatales, como la actividad del buzo, que busca un agujero en el océano que, según su teoría descabellada, pudiera ser la causa de las erupciones marítimas (00:51:47-00:54:24) (Shaw 2003: 96-97; Franz 1997: s.p.). Antes de señalar los diferentes significados simbólicos habría que destacar una capa referencial del maremoto que se puede relacionar con el maremoto real que tuvo lugar en 1960 con su epicentro en Valdivia. El maremoto, que provocó un tsunami muy fuerte, causó la muerte de miles de personas, inundaciones devastadoras y daños graves en gran parte de las ciudades de la IX y X región, como Puerto Montt, Los Ángeles, Valdivia y Concepción (Bizzarro 2005: 235). ${ }^{12}$

En la película, el maremoto representa un Leitmotiv tan expresivo como ambivalente que remite a las experiencias políticas y sociales de los años de la dictadura en Chile y, con ello, ha provocado interpretaciones diversas por parte de los críticos. La mayoría de ellos coincide en la ambigüedad de la metáfora. Según Deborah Shaw, el maremoto representa las erupciones de las diferentes fuerzas políticas chilenas, desde el golpe militar en 1973 hasta el proceso de resistencia, y la lenta apertura hacia la democracia en los últimos años de la dictadura (Shaw 2003: 98). La presencia inquietante del primer maremoto en la memoria del pueblo remitiría entonces a los efectos intimidantes del golpe de Estado en la conciencia colectiva, mientras que la llegada del segundo tsunami implicaría la ruptura con el régimen y la salida hacia un futuro democrático. Bettina Bremme confirma el carácter ambiva-

12 La catástrofe destruyó casi todo Puerto Saavedra, uno de los lugares de rodaje de la película. 
lente del fenómeno marítimo constatando que la ola conlleva un elemento atávico, a la vez destructor y purificante (Bremme 2000: 85). Para Carlos Franz, en cambio, la erupción del segundo maremoto implica más bien la pérdida de las esperanzas políticas e individuales y deja a los personajes como náufragos, condenados a una lucha perpetua (Franz 1997: s.p.). El maremoto provoca la muerte de los españoles y del buzo, un aspecto que refuerza el carácter ambiguo y desconcertante de la metáfora. Otro aspecto problemático de todos estos significados políticos que conlleva la metáfora parece resultar de la aparente relación fatalista entre los hechos históricos y la catástrofe natural, que parecería sugerir que tanto el Golpe como las movilizaciones sociales de resistencia son consecuencia de un destino fatal inevitable y no están sujetas a los actos de los hombres mismos.

Finalmente, la inundación provocada por el tsunami implica elementos teológicos y míticos: situada al final de la película y puesta en escena con imágenes oscuras e inquietantes, por un lado recuerda al Apocalipsis (Franz 1997: s.p.) o al Diluvio (Hart 2004: 149f.) bíblicos; por otro lado se lo relaciona con el mito mapuche de "Tenténvilu" (00:55:35-00:55:40) que narra el conflicto entre una diosa terrena y la zorra marítima Coicoi-vilu (Shaw 2003: 97). Con todo ello, la película adquiere una calidad mítica que se podría denominar "de otro mundo" ("otherwordly quality", Shaw 2003: 97; 01:42:58-01:48:36), y así transgrede el nivel de la ambientación territorial y un significado denotativo concretos, ofreciendo al espectador interpretaciones utópicas y/o distópicas de la catástrofe natural sin decidirse nunca definitivamente por una.

En contraste, el buzo representa una figura meramente positiva. Tiene la teoría de que el océano consiste de dos mares separados que están unidos por un agujero submarino escondido: cuando las masas de abajo se calientan, se produce, según él, el tsunami destructor -su solución para evitar la devastación sería entonces encontrar y rellenar este hueco escondido. Según Burriel, es el mar de arriba que representa al régimen represivo mientras que las masas de abajo simbolizan a las fuerzas populares y de resistencia (Burriel 1998: 201).

Cuando el buzo habla de su esperanza de poder descubrir en el futuro las causas del maremoto y así encontrarle una solución a la violenta amenaza, la cámara nos muestra al personaje en el punto más alto de un cerro desde donde se puede ver el mar. De hecho, es uno de 
los pocos momentos de la película en que se muestra un paisaje sereno. Mientras que la música, a su vez, subraya el tono esperanzador de la búsqueda idealista, podemos observar en el horizonte un arco iris que alude a las posibilidades de un futuro libre y democrático (00:51:46) (Shaw 2003: 96). ${ }^{13}$ Al final del film, el buzo y Ramiro arrastran desde el mar la estatua del "Abrazo de Maipú" que representa al general O'Higgins -figura simbólica de la independencia de Chile- junto con San Martín (01:33:35-01:34:50). El hallazgo es otra metáfora política que expresa la esperanza de un futuro constructivo de base democrática, y remite a la vez a la solidaridad transnacional histórica entre Chile y Argentina que los militares a ambos lados de los Andes transformaron en hostilidad bélica. Dado que constituye otro signo material de la Historia nacional, el monumento resalta de nuevo la importancia de la memoria cultural, y apunta de manera autoreflexiva al propio papel de la película en este proceso.

Con su búsqueda incansable e idealista de un futuro mejor, el buzo personifica una visión utópica de la transición hacia la democracia. En cambio, podemos interpretar el agujero como metáfora negativa de "todo lo malo" en el país: representa a la vez la carencia, el vacío, el olvido y el terror -es decir que figura como símbolo distópico- (Shaw 2003: 96-97). ${ }^{14}$ La muerte del buzo en el maremoto, sin embargo, relativiza también aquí la actitud exclusivamente optimista del personaje y apunta a las posibles dificultades y obstáculos en el camino hacia este futuro postdictatorial positivo.

En comparación con Sur, en La frontera los espacios de simbolización positiva o negativa tanto como los conceptos de exilio o de compromiso social se manifiestan de manera menos clara e inequívoca. A pesar de que el título nos sugiere a primera vista una separación determinante entre los espacios geográficos y conceptos sociales, entre la dictadura y la libertad, lo bueno y lo malo, lo propio y lo ajeno, la película gira justamente alrededor de la transgresión de los límites

13 Hart (2004: 150) apunta otra vez a la dimensión bíblica de esta escena (libro de Job).

14 "The hole is a dystopian symbol for all that is wrong; it can be seen to represent lack, disharmony, emptiness, the forgotten past. The urge to find and fill the hole takes on a mythical dimension and can be seen as part of the history of the search for the utopian dream. In an inverse reworking of the biblical myth of the Promised Land, the search here is for the causes of destruction, to find peace and harmony to create a new land" (Shaw 2003: 96-97). 
de todos estos conceptos binarios, remitiendo más bien a su entramado indisoluble. El film plantea fronteras que va deconstruyendo al mismo tiempo. Ahí está, por ejemplo, la frontera natural entre isla y tierra firme que produce el aislamiento de Ramiro, pero que al final de cuentas también le otorga el espacio para desarrollarse y volver a afirmar su denuncia política defendiendo así su libertad personal. El mar, a su vez, constituye una frontera natural que, simultáneamente, separa y une a los hombres: con sus erupciones violentas y como línea fronteriza por un lado, y por otro como pasaje entre isla y tierra o España y Chile. El aislamiento y exilio interior también son estados psicológicos que al mismo tiempo son planteados y transgredidos en la película. Queda abierto, por ejemplo, dónde empieza el exilio interior y dónde empieza el destierro oficial, cuáles son actos de resistencia y cuáles más bien comportamientos de resignación y retraimiento social.

Shaw ha destacado de manera convincente este aspecto de fluctuación transgresora afirmando que

[t]he notion of the frontier normally implies a crossing from one point to another, a bridge to be crossed on the journey to a destination; however, this film remains in the borderland. Set in the spaces in between, The Frontier is a film without certainties, where dichotomies are blurred (Shaw 2003: 89).

La imaginación del sur oscila, también en La frontera, entre un nivel político-histórico concreto, y la construcción de un espacio irreal, utópico o distópico, entrecruzando esta vez de manera inseparable los aspectos más contradictorios de sufrimiento y esperanza.

\section{Un lugar de memoria polisemántico}

Como espacio geográfico, el sur tiene en ambas películas un carácter referencial, ya que remite a la violencia concreta en forma del destierro y el encarcelamiento de presos políticos en la región austral americana durante ambos regímenes dictatoriales. Además de esto, la inclinación hacia una estética anti-mimética, o mítico-poética, refuerza en ambos casos el predominio del significado connotativo del espacio. En ambos filmes, la zona adquiere una función simbólica muy importante: por su localización periférica, constituye un espacio en el que al mismo tiempo se vuelcan los deseos y fantasías utópicas y distópicas. Siguiendo a Nelly Richard, podríamos interpretar esta paradoja, entre 
otras cosas, como síntoma de un estado transitorio y de la consecuencia del conflicto entre el deseo de "re-integrar lo desintegrado" (Richard 2003: 289), es decir, el intento de recuperar los grandes proyectos ideológicos de la izquierda y la conciencia de un duelo permanente y una pérdida irrecuperable.

En Sur, las experiencias extremas y esperanzas humanas son desplazadas hacia la periferia en un gesto de transposición geográfica. Con su puesta en escena polarizada, la película plantea un discurso explícitamente en contra del régimen militar, construyendo el sur como lugar de experiencias fuera de la "normalidad" o realidad argentina: la heterotopía de la cárcel-penal, la utopía de un futuro justo y humano.

En cambio, La frontera se muestra mucho menos explícita ya que no tematiza tan abiertamente la violencia y en su lugar opta por una denuncia indirecta. El film plantea el microcosmos de una sociedad (post-)dictatorial fuertemente marcada por el autoritarismo y quizás desarrolla su efecto inquietante precisamente por sus ambivalencias preocupantes a varios niveles. Lira (2001: 52) sostiene que "[1]a experiencia de miedo y paralización por el horror existente y el riesgo de padecerlo es tal vez la experiencia más masiva en la sociedad chilena en el período post 73" Raffin (2006: 157-158) afirma que

[...] las dictaduras del Cono Sur se apoyaron en, al tiempo que construyeron, un estado terrorista que fue acompañado asimismo y necesariamente, por la instauración de un cierto modelo social y de una cultura del miedo.

Más que una explícita "memoria del terror", se construye aquí en analogía una "memoria del miedo" -lo que remite a su vez a aspectos de la realidad postdictatorial chilena que sigue afectada de manera significativa por la experiencia del temor. ${ }^{16}$

15 'La 'cultura del miedo' implica un achicamiento del espacio público al tiempo que un repliegue del individuo sobre sí mismo, lo que acarrea la ruptura de los lazos de solidaridad social horizontal; actualiza antiguos miedos, alienta la desconfianza y tiende a la delación. Ante la imposibilidad de poner en práctica aquello que se imagina, el acto de pensar, reflexionar e imaginarse una alternativa, ya es, en sí mismo, subversivo en el contexto de una cultura del miedo" (Raffin 2006: 158).

16 "Chileans watching this film in 1991 were also in the borderland between dictatorship and democracy, attempting to build a democratic society with Augusto Pinochet still head of the armed forces" (Shaw 2003: 96). 
Otro aspecto a destacar es la relación del tema del exilio, tal como se lo plantea en Sur y La frontera, con la puesta en escena de la localización geográfica en ambas películas. Solanas ha elaborado el tema del exilio en Tangos... en detalle. En Sur, tenemos por un lado un personaje extradiegético que acaba de volver del exilio europeo a Buenos Aires y representa el destinatario ficticio de la historia que la película va narrando. Por otro lado está el exilio interior de María, localizado en la Patagonia y relacionado con imágenes cinematográficas luminosas y positivas. También los personajes que se quedan en Buenos Aires, como Rosi, experimentan una forma de exilio interior. La cárcel de la Patagonia parece estar claramente opuesta a estos estados ya que aquí se trata de un encierro físico muy determinado. Sin embargo, en la medida que Floreal va interiorizando las normas represivas del lugar, vemos cómo el encierro físico se va transformando poco a poco en un exilio interior.

Resulta significativo que el título inglés de La frontera es justamente The Exile. Con ello, se indica una significación más restringida de la que propone el título original que, como hemos visto, apunta precisamente hacia los significados plurivalentes del film. En La frontera, el tema de exilio se presenta desde el principio como un concepto menos concreto y explícito. Primero está el destierro de Ramiro que oscila entre la reclusión física y el exilio interior. Después son sobre todo los dos personajes españoles, la bibliotecaria Maite y su padre, quienes personifican la experiencia del exilio también de los muchos chilenos emigrados bajo la dictadura. Los dos parecen vivir fuera del tiempo y del lugar, desterrados de su patria y perdidos en sus anhelos y sueños nostálgicos. Luego está también la ex-mujer de Ramiro que viene a visitarlo con el hijo y su nueva pareja viniendo desde su exilio holandés (01:09:52-01:15:10). Su aparición muestra la lejanía emocional entre la ex-pareja y apunta de manera reveladora a la idealización estereotipizada de los exiliados chilenos por una parte de las izquierdas europeas ya que la exiliada se queja de los clichés y proyecciones a los que se ve confrontada al otro lado del Atlántico.

En resumen, no sorprende mucho que, por la lejanía de los centros urbanos políticos y culturales y el aislamiento geográfico (acentuados por las situaciones en el centro de detención y la insularidad correspondientes), el sur en ambos casos se relaciona fácilmente con el tema del exilio (tanto físico como psicológico). 
Como hemos visto, destaca en ambas películas una inclinación hacia la metáfora, la alegoría y la discursividad en las representaciones del espacio. Además, podemos observar en los dos filmes los "mecanismos de transposición" que destaca Julia Kristeva como elementos esenciales del procesamiento del pasado (Kristeva, citado por Richard 2003: 289), por ejemplo, los desplazamientos geográficos en Sur (heterotopía de la cárcel) e histórico-políticos en La frontera (tema de la Guerra Civil española).

Finalmente cabe mencionar el papel que se le otorga de manera explícita a la memoria textual y material: en Sur, tenemos como modelo constructivo liberador el "archivo Sur", en el que se guardan los textos de los pensadores liberales y democráticos; como ejemplo represivo, en cambio, se presenta a la oficina de censura que descalifica y hace desaparecer miles de libros "subversivos" en un acto destructor. En La frontera son sobre todo los dos exiliados españoles que personifican el trabajo de la memoria con sus actividades en la biblioteca pública y sus archivos privados de fotografías y periódicos. En ambas películas, los trabajos de la memoria cultural se encuentran en peligro (o por la represión estatal, o por el clima húmedo y la catastrofe natural que remite a su vez a la política de represión).

En un gesto autoreflexivo, los filmes apuntan así al importante papel de la labor de la cultura en el proceso de democratización y procesamiento del pasado. La autoreflexividad es reforzada tanto en Sur como en La frontera por la estética anti-realista y elementos metanarrativos, como el personaje del narrador en Solanas y la aparición del equipo de televisión delante el cual Ramiro repite su denuncia en Larraín (01:49:50-01:50:30). Como indica Nora, los lugares de memoria son "objetos dobles", abiertos a significados múltiples, que refieren a su propio carácter construido: "Tous les lieux de mémoire sont des objets en abîme" (Nora 1984: XXXVII). Las dos películas aquí analizadas (re-)construyen una memoria cultural mientras que al mismo tiempo apuntan hacia su propia condición de obra de arte construida.

Para concluir, podemos resumir que las películas proponen una visión fílmica del sur que se aleja de las proyecciones míticas y turísticas tradicionales de esta zona austral americana. Junto con los monumentos ya establecidos y otros documentos y obras de arte que rescatan la memoria de la Historia reciente en esta región, se va construyendo un lugar de memoria que nos remite de manera metonímica y 
simbólica al terror del Estado en Argentina y Chile. El sur representa un lugar de memoria polisemántico que remite tanto al terror como a la esperanza, tanto a la experiencia dictatorial de una zona geográfica concreta como a la memoria colectiva de los dos países. En ambas películas, la región oficia de "lugar otro" para elaborar de manera sustitutiva los traumas de la dictadura y articular esperanzas individuales y colectivas, constituyendo un lugar cultural en el que se cruzan el pasado, el presente y el futuro.

\section{Filmografía}

Larraín, Ricardo (1991): La frontera. Chile/España.

- (1999): El entusiasmo. Chile/Francia/España.

Solanas, Fernando (1968): La hora de los hornos. Argentina.

- (1985): Tangos... el exilio de Gardel. Argentina/Francia.

- (1988): Sur. Argentina/Francia.

- (1992): El viaje. Argentina/México/Francia/España/Reino Unido.

- (2004): Memoria del saqueo. Argentina/Suiza/Francia.

Sorín, Carlos (2002): Historias mínimas. Argentina/España.

\section{Bibliografía}

Bizzarro, Salvatore (2005): Historical Dictionary of Chile. Lanham/Toronto/Oxford: The Scarecrow Press.

Bremme, Bettina (2000): Movie-mentos. Der lateinamerikansiche Film: Schlaglichter von unterwegs. Stuttgart: Schmetterling.

Burriel Llombart, Jaime (1998): "A propósito de la historia reciente de Chile: $L a$ frontera, entre la realidad y la ficción". En: Alcàzar, Joan del/Tabanera, Nuria (eds.): Estudios y materiales para la historia de América Latina 1955-1990. Valencia: Tirant lo Blanch, pp. 191-203.

Calveiro, Pilar (2002): Desapariciones: memoria y desmemoria de los campos de concentración argentinos. México, D.F.: Taurus.

Carreño, María Francisca (2002): Cine chileno, 1990-1999: una década de imágenes en movimiento. Tesis de licenciatura, Santiago: PUC.

Ciria, Alberto (1995): Más allá de la pantalla. Cine argentino, historia y política. Buenos Aires: Ediciones de la Flor.

Dujovne Ortiz, Alicia (1996): "Neuquén, Ushuaia, Trelew: trois prisons extrêmes". En: Schneier-Madanes, Graciela (ed.): Patagonie. Une tempête d'imaginaire. Paris: Éditions Autrement, pp. 198-204.

Foster, David William (1992): Contemporary Argentine Cinema. Columbia/London: University of Missouri Press. 
Foucault, Michel (1994): "Des espaces autres". En: Foucault, Michel: Dits et Ecrits.1954-88. Vol. 4. Paris: Gallimard, pp. 752-762.

Franz, Carlos (1997): "Ricardo Larraín en la frontera". En: <www. cervantesvirtual.com/servlet/SirveObras/p243/12482062007028203087624/ p0000001.htm\#I_0_> (05.05.2009).

Hart, Stephen M. (2004): A Companion to Latin American Film. Woodbridge: Tamesis.

Lillo, Gastón (1995): "El cine y el contexto político-cultural en el Chile de la posdictadura”. En: Revista Canadiense de Estudios Hispánicos, 20, 1, pp. 31-42.

Lira, Elizabeth (2001): "Memoria y olvido". En: Olea, Raquel/Grau, Olga (eds.): Volver a la memoria. Santiago: LOM, pp. 45-60.

Nora, Pierre (1984): "Entre Mémoire et Histoire. La problématique des lieux". En: Nora, Pierre (ed.): Les lieux de mémoire. Vol. 1. Paris: Gallimard, pp. XVIIXLII.

Oubiña, David (1994): “Exilios y regresos”. En: España, Claudio (ed.): Cine argentino en democracia 1983/1993. Buenos Aires: Fondo Nacional de las Artes, pp. 68-81.

Pons, María Cristina/Soria, Claudia (2005): "El mito del sur en el cine argentino: entrevista a Claudio España”. En: Pons, María Cristina/Soria, Claudia (eds.): Delirios de grandeza. Los mitos argentinos: memoria, identidad, cultura. Rosario: Beatriz Viterbo, pp. 245-272.

Raffin, Marcelo (2006): La experiencia del horror. Subjetividad y derechos humanos en las dictaduras y posdictaduras del Cono Sur. Buenos Aires: Del Puerto.

Richard, Nelly (2003): "Las reconfiguraciones del pensamiento crítico en la posdictadura". En: Jáuregi, Carlos A./Dabove, Juan Pablo (eds.): Heterotopías. Narrativas de identidad y alteridad latinoamericana. Pittsburgh: Instituto Internacional de Literatura Iberoamericana, pp. 287-298.

Shaw, Deborah (2003): Contemporary Cinema of Latin America. Ten Key Films. New York/London: Continuum.

Solanas, Fernando "Pino" (1989): La mirada. Reflexiones sobre cine y cultura. Entrevista de Horacio González. Buenos Aires: Puntosur.

Villarroel M., Mónica (2005): La voz de los cineastas. Cine e identidad chilena en el umbral del milenio. Santiago: Editorial Cuarto Propio. 